\title{
Using a long semi-rigid catheter with a controllable tip to facilitate tracheal intubation with a GlideScope ${ }^{\circledR}$
}

\author{
Dmitri Bezinover, MD, PhD · Matthew Desciak, MD • \\ Sonia J. Vaida, MD · Leonardus Pott, MD
}

Received: 18 June 2009/Accepted: 27 June 2009/Published online: 28 July 2009

(C) Canadian Anesthesiologists' Society 2009

\section{To the Editor,}

The recently developed GlideScope ${ }^{\circledR}$ (GS) (Original model, Verathon Inc., Bothel, WA, USA) has become very popular for managing both difficult and routine tracheal intubations. The GS allows improved visualization of the vocal cords, but occasionally inserting the endotracheal tube (ETT) may be difficult. ${ }^{1}$ In cases where the glottic opening is situated very anterior, the ETT tends to be directed into the larynx with an angle almost perpendicular to the axis of the trachea. This situation can lead to the failure of intubation.

A number of solutions for this well-known problem have been suggested already, including the use of a preformed stylet or an Eschmann ${ }^{\circledR}$ Tracheal Tube Introducer (gum elastic bougie), ${ }^{2,3}$ or possibly using a combination of a GlideScope ${ }^{\circledR}$ and a fibreoptic bronchoscope (FOB) to facilitate intubation. ${ }^{4,5}$ This latter combination is especially beneficial when the GS view is suboptimal. We frequently use this technique, and in our view, the crucial factor for success is the FOB's flexibility, which allows the ETT to pass easily through the glottis. In the majority of cases, the fibreoptic bronchoscope is not absolutely necessary and could be replaced by a catheter with a controllable tip.

Unfortunately, this type of equipment is not freely available; therefore, we recommend using a special type of endobronchial blocker, namely, the Cook ${ }^{\circledR}$ Cohen Tip Deflecting Endobronchial Blocker Set (Cook Critical Care, Bloomington, IN, USA). This device consists of a long

D. Bezinover, MD, PhD $(\bowtie) \cdot M$. Desciak, MD

S. J. Vaida, MD · L. Pott, MD

Pennsylvania State University College of Medicine,

Penn State Hershey Medical Center, Hershey, USA

e-mail: dbezinover@hmc.psu.edu

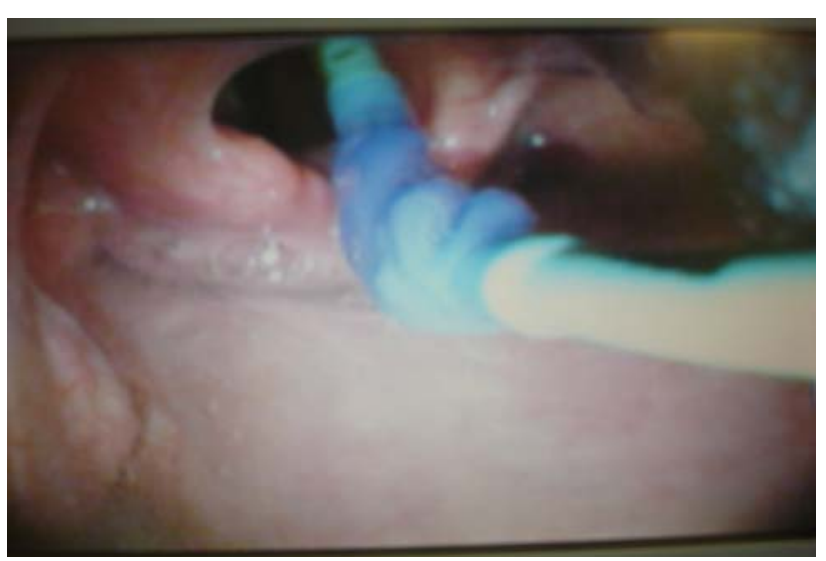

Fig. 1 Insertion of the catheter with flexed tip into the trachea

semi-rigid catheter with a controllable distal tip that can be flexed by rotating a small steering wheel at the proximal end of the endobronchial blocker. This manipulation enables the catheter to be directed into the trachea in cases where the vocal cords are situated very anterior (Fig. 1). The ETT can then be passed easily over the catheter. One clinician can manage the tracheal intubation without additional help. We have successfully performed tracheal intubations on eleven patients using this procedure.

To our knowledge, the endobronchial blocker set $\left(\right.$ Cook $\left.^{\circledR}\right)$ is the only device that has the ability to steer the tip of the catheter in different directions. This endobronchial blocker is relatively expensive, but a catheter with an adjustable tip may be considered a prototype. The development of a simple device with a controllable tip would be a useful adjunct for indirect laryngoscopic intubation techniques.

Conflicts of interest None of the authors has commercial or noncommercial interests that may be considered a conflict of interest in this work. 


\section{References}

1. Cooper RM, Pacey JA, Bishop MJ, McCluskey SA. Early clinical experience with a new videolaryngoscope (GlideScope) in 728 patients. Can J Anesth 2005; 52: 191-8.

2. Turkstra TP, Harle CC, Armstrong KP, et al. The GlideScopespecific rigid stylet and standard malleable stylet are equally effective for GlideScope use. Can J Anesth 2007; 54: 891-6.

3. Budde AO, Pott LM. Endotracheal tube as a guide for an Eschmann gum elastic bougie to aid tracheal intubation using the McGrath ${ }^{\circledR}$ or GlideScope ${ }^{\circledR}$ videolaryngoscopes. J Clin Anesth 2008; 20: 560.
4. Sukernik MR, Bezinover DS, Stahlman B, Vaida S, Pott L. Combination of Glidescope with fiberoptic bronchoscope for the optimization of difficult endotracheal intubation. A case series of three patients. Anesthesia On-Line, January 2009. http://www. priory.com/medicine/Glidescope_bronchoscope.htm. Accessed June 2009.

5. Greib N, Stojeba N, Dow WA, Henderson J, Diemunsch PA. A combined rigid videolaryngoscopy-flexible fibrescopy intubation technique under general anesthesia. Can J Anesth 2007; 54: 492-3. 